Bartłomiej Krupa

\title{
O nieobecności Zagłady, czyli czytanie Rozmów z katem Kazimierza Moczarskiego
}

Rozmowy z katem Kazimierza Moczarskiego ${ }^{1}$, których głównym bohaterem jest odpowiedzialny za likwidację getta warszawskiego Jürgen (Josef) Stroop, znalazły się na uzupełniającej liście lektur z języka polskiego dla liceów w roku szkolnym 1983/1984. Figurowały na niej do reformy oświaty wprowadzonej w 1999 r. ${ }^{2}$ Dodatkowo, od roku szkolnego 1992/1993 dwa krótkie fragmenty Rozmów umieszczono w podręczniku Bożeny Chrząstowskiej, Ewy Wiegandt i Seweryny Wysłouch Literatura wspótczesna dla klas maturalnych ${ }^{3}$. Z czasem książka Moczarskiego została wycofana $\mathrm{z}$ listy lektur ${ }^{4}$, lecz jej rola $\mathrm{w}$ formowaniu społecznego wyobrażenia nazisty

${ }^{1} \mathrm{~W}$ miejscach, w których cytuję tekst książki, korzystam z wydania: Kazimierz Moczarski, Rozmowy z katem, oprac. Andrzej Krzysztof Kunert, Warszawa: Wydawnictwo Naukowe PWN, 2001. Dalej oznaczam jako RzK z podaniem numeru strony za tym wydaniem.

${ }^{2}$ Por. Andrzej Franaszek, Od Bieruta do Herlinga-Grudzińskiego. Wykaz lektur szkolnych $w$ Polsce w latach 1946-1999, Warszawa: Biblioteka Narodowa, 2006, s. 152.

${ }^{3}$ Zob. na przykład Bożena Chrząstowska, Ewa Wiegandt, Seweryna Wysłouch, Literatura wspótczesna. Podręcznik dla klas maturalnych, Poznań: Wydawnictwo Nakom, 1996, s. $274-275$.

${ }^{4}$ Zmiany w kanonie lektur szkolnych obserwowane pod kątem ewolucji dyskursu na temat Zagłady są same w sobie niezwykle interesującym zagadnieniem, które wymagałoby rozwinięcia. Tu ograniczam się tylko do ram, w których mieści się książka Moczarskiego. W rozporządzeniu ministra edukacji narodowej z $21 \mathrm{~V} 2001 \mathrm{r}$. w sprawie podstawy programowej kształcenia ogólnego w poszczególnych typach szkół oraz kształcenia w profilach w liceach profilowanych (DzU z 19 VI 2001 r., załącznik nr 6) książka Moczarskiego nie jest wymieniona, ale pojawia się na liście lektur zapis: „wybrany utwór z literatury dokumentalnej (reportaż, dziennik, pamiętnik)”, który daje możliwość wykorzystania Rozmów z katem na lekcjach języka polskiego. Podobny zapis widnieje na podpisanym 23 VIII 2007 r. przez Ryszarda Legutkę (ówczesnego ministra edukacji narodowej), projekcie listy lektur szkolnych. Na liście dla szkół ponadgimnazjalnych pod numerem 30. pojawia się zapis: „Inne wybrane fragmenty prozy dokumentalnej (reportaż, dziennik, pamiętnik) i eseistycznej” (DzU z 31 VIII 2007 r., nr 157, poz. 1100). Na obecnie obowiązującej (rok szkolny 2011/2012) liście lektur, przygotowanej zgodnie z podstawą programową (ostatnie zmiany: Rozporządzenie MEN z 29 VIII 2008 r., DzU z 2 IX 2008 r., nr 159, poz. 992), Informatorem maturalnym od 2008 r. z języka polskiego oraz Komunikatem dyrektora CKE w sprawie listy lektur dla szkót ponadgimnazjalnych na egzamin maturalny od maja 2009 roku (http://www.cke.edu.pl/ 
wśród kilku pokoleń Polaków nie ulega najmniejszej wątpliwości. Zwłaszcza jeśli dodamy do tego teatralne adaptacje Rozmów. Tymczasem o książce Moczarskiego, w znacznej przecież części poświęconej Holokaustowi, nawet nie wspominają najważniejsze polskie syntezy literatury dotyczącej Zagłady - począwszy od Tematów żydowskich $w$ prozie polskiej 1939-1987 Józefa Wróbla, skończywszy choćby na opracowaniu zbiorowym Stosowność i forma pod redakcją Michała Głowińskiego czy monografii Świadectwo - trauma - głos Aleksandry Ubertowskiej ${ }^{5}$. Brakuje również interpretacji oraz kompleksowych, analitycznych omówień tego tekstu ${ }^{6}$.

Z czego wynika owa rozbieżność pomiędzy społecznym - nawet jeśli sztucznie (tj. szkolnie) wywołanym - zakorzenieniem a brakiem pogłębionej refleksji nad kształtem narracji Moczarskiego i sensem, jaki ona przemyca? Czy rozbieżność ta powstała w wyniku niejasności genologicznych, a więc różnych odpowiedzi padających na pytanie, z jakim rodzajem opowieści mamy tu do czynienia - zapisem dokumentarnym (pamiętnik, relacja, wspomnienie), literaturą piękną lub beletrystyką (biografia, utwór prozatorski), czy też hybrydą, którą umownie można zaklasyfikować jako literaturę faktu lub reportaż? Może zaś porządek lektury zawładnięty został przez jeden dominujący sens, który nie pozwala widzieć w tej książce opowieści o Holokauście?

Chciałbym się przyjrzeć polskiej recepcji książki Moczarskiego. Układ mojej opowieści podpowiadają trzy główne edycje Rozmów. Poprzedzone są one niezwykle wymownymi wprowadzeniami, wyznaczającymi pewne sensy lektury i będące zarazem tej lektury świadectwami:

- edycja Państwowego Instytutu Wydawniczego ze wstępem Franciszka Ryszki (pięć wydań w latach 1977-1985),

- edycja Państwowego Wydawnictwa Naukowego/Wydawnictwa Naukowego PWN ze wstępem Andrzeja Szczypiorskiego (dziesięć wydań w latach 1992-2002) oraz

- edycja Znaku ze wstępem Normana Daviesa (od 2004 r. trzy wydania).

Interesuje mnie przy tym nie tyle sam tekst, do którego wrócę na moment w epilogu, ile raczej to, co się wokół niego działo, co przydarzało mu się w odbiorze społecznym. Przyjrzę się historii jego wydań i odczytań, czyli przekształceń w obrębie

images/stories/Komunikaty_08_09/lektury_2009_matura_a.pdf, dostęp 10 X 2011 r.), książka Moczarskiego nie figuruje, ale nauczyciel sam może zadecydować o wykorzystaniu jej fragmentów na lekcji języka polskiego.

${ }^{5}$ Stosowność i forma. Jak opowiadać o Zagładzie?, red. Michał Głowiński i in., Kraków: Universitas, 2005.

${ }^{6}$ Najpełniejsza - i skądinąd bardzo interesująca - analiza książki wyszła spod pióra Zofii Mitosek. Ukazała się ona pierwotnie pt. Semantyczne aspekty literatury faktu w: „Z Polskich Studiów Slawistycznych” 1988, seria 7, cz. 2, s. 205-213. Później tekst ten został przedrukowany w: Zofia Mitosek, Mimesis, Warszawa: Wydawnictwo Naukowe PWN, 1997, s. 267-280, oraz eadem, Co poznaje dokument? (Kazimierz Moczarski „Rozmowy z katem”) [w:] eadem, Poznanie (w) powieści - od Balzaka do Masłowskiej, Kraków: Universitas, 2003, s. 252-263. Dalej tekst ten cytuję za ostatnim z wymienionych źródeł. 
nadawania mu rozmaitych sensów. Zwrócę przy tym głównie uwagę na społeczny wizerunek kata oraz wyobrażenia (lub raczej ich brak) Zagłady, jakie się przy okazji odbioru Rozmów z katem wyłaniały. Z tego powodu nie rozważam dalej pytania, od którego rozpoczyna się wiele recenzji - czy Rozmowy to wywiad, pamiętnik, a może reportaż? Te dyskusje uznałem po prostu za akademickie lub mówiąc dosadniej - jałowe, bo w istocie czy coś się w opowiadaniu Zagłady zmieni, jeśli nazwiemy książkę Moczarskiego reportażem, a nie pamiętnikiem? Milcząco zakładam dalej, że mamy w wypadku Rozmów do czynienia z immanentnie sylwiczną formą.

\section{Zanim ukazała się książka}

Na wstępie kilka szczegółów biograficznych. Kazimierz Moczarski urodził się w 1907 r. Przed wojną ukończył prawo na Uniwersytecie Warszawskim oraz w Instytucie Prawa Międzynarodowego w Paryżu, był dziennikarzem, pracownikiem Ministerstwa Opieki Społecznej, politycznie związał się zaś ze Stronnictwem Demokratycznym. W czasie okupacji wstapił do ZWZ-AK, od sierpnia 1942 r. pracował w Wydziale Informacji Biura Informacji i Propagandy Komendy Głównej AK (od kwietnia 1945 r. był jej szefem). Od stycznia 1944 r. zarządzał także działem dochodzeniowo-śledczym w Okręgowym Kierownictwie Walki Podziemnej Warszawy. Podczas powstania warszawskiego kierował stacją informacyjno-radiową, redagował też dziennik AK „Wiadomości Powstańcze”. W dniu 11 sierpnia 1945 r. został aresztowany przez stalinowską policję bezpieczeństwa i osadzony w więzieniu mokotowskim. W śledztwie torturowany, a następnie skazany na 10 lat za działalność w AK. W 1948 r. proces Moczarskiego wznowiono i w 1952 r. wydano na niego wyrok śmierci, o którym dowiedział się dopiero trzy lata później. To właśnie podczas tego wznowionego procesu, od 2 marca do 11 listopada 1949 r., przebywał w jednej celi z Jürgenem Stroopem - likwidatorem getta warszawskiego. W kwietniu $1956 \mathrm{r}$. na fali odwilży Moczarski został zwolniony z więzienia, a w grudniu tegoż roku, po głośnym procesie, zrehabilitowany?

Rozmowy z katem zaczęły powstawać tuż po wyjściu autora z więzienia w $1956 \mathrm{r}$. Moczarski wspomina o tym w wywiadzie udzielonym Mieczysławowi Orskiemu:

[Jeszcze w więzieniu] umiałem pisać w myśli, wyobrażając przed sobą kartkę papieru, i to tak, że mogłem potem wracać do jakiegoś oznaczonego miejsca na tej kartce. Zresztą, ciągle te kartki «wertowałem», wracałem do nich, już po rozstaniu ze Stroopem [...] w momencie wyjścia na wolność, w kwietniu 1956, zachowałem stan stuprocentowej pamięci. A ponieważ bałem się, że wspomnienia rzeczywiście szybko stępieją, zacząłem z punktu zapisywać, trochę bezładnie, niechronologicznie, skrótami. Umiejętność skrótowego zapisu wydoskonaliłem w konspiracji, działając w sztabie KG Armii Krajowej.

${ }^{7}$ Na temat życiorysu Moczarskiego zob. na przykład: Andrzej Krzysztof Kunert, Kalendarium życia autora (RzK, s. 404-410). Obszerny szkic biograficzny znaleźć można również w: idem, Kazimierz Moczarski (1907-1975) [w:] Kazimierz Moczarski, Zapiski, oprac. Andrzej Krzysztof Kunert, Warszawa: PIW, 1990, s. 7-114. 
Zapisałem wtedy około tysiąca stron notatek. Najważniejsze dane: daty, fakty, nazwiska. Pierwszą historią, jaką zanotowałem, było opowiadanie Stroopa o jego działalności na Ukrainie ${ }^{8}$.

$\mathrm{Z}$ czasem autor swoje notatki wzbogacał, poszerzając je o informacje pozyskane podczas przeglądania w siedzibie Głównej Komisji Badań Zbrodni Hitlerowskich akt sprawy Stroopa, zapoznawania się z przesłaną mu przez przyjaciół ze Stanów Zjednoczonych kopią akt jego procesu w Dachau, wreszcie książkami historycznymi oraz zdobytymi prospektami i planami Detmoldu' ${ }^{9}$. Wiele wskazywało na to, że przygotowana $\mathrm{w}$ ten sposób książka szybko ujrzy światło dzienne. Jak pisze w biografii Moczarskiego Anna Machcewicz, jesienią 1961 r. „publikacją zainteresowane były Iskry, wydawnictwo planowało uczcić w ten sposób dwudziestą rocznicę powstania w getcie warszawskim w kwietniu 1963 roku"10. Mimo intensywnej pracy autora, który napisał w jednym z listów z tego czasu: „książka o Stroopie jest najważniejszą sprawą mego życia”"11, do opublikowania Rozmów jednak nie doszło. Pierwsze fragmenty ukazały się dopiero w roku 1968.

W czerwcowym numerze „Polityki”, którą otwierał poświęcony studenckiej rewolcie na Zachodzie artykuł Daniela Passenta pt. Stabość $i$ siła studentów, wydrukowano na całej stronie osiem fragmentów-kapsułek Rozmów, układających się w minibiografię Stroopa. Pojawiły się tu:

- Pierwszy dzień (scena spotkania i spożywania w milczeniu pierwszego wspólnego posiłku przez trójkę więźniów),

- Parteitag (relacja na temat parady, którą kierował Stroop),

- Czego Niemcy nie lubią (opisujące wejście wojsk niemieckich do Czechosłowacji),

- Selbstschutz w Poznańskiem (o poczynaniach Stroopa w Wielkopolsce),

- Powstanie w getcie warszawskim (wyimki dotyczące likwidowania powstania),

- Zawrotna kariera (o tym, jak Stroop z porucznika stał się generałem SS),

- Lincz jako metoda (o likwidowaniu przez Stroopa amerykańskich lotników),

- Udawał niewiniątko (o tym, jak Moczarskiego zawiodły nerwy i cisnął w Stroopa szmatą, oraz opinia Augusta Schielkego o nielojalnej postawie Stroopa w czasie procesu, a także opis egzekucji) ${ }^{12}$.

Już w tym pierwszym - selektywnym przecież - wyborze widać zalążek późniejszych interpretacji książki. Głównym bohaterem narracji jest z całą pewnością Jürgen Stroop. To jego historię mamy poznać przede wszystkim i to ona determinuje strukturę całości. Taka interpretacja dominować będzie do przełomu 1989 r., taką

${ }^{8}$ Jak powstawały „Rozmowy z katem”, z Kazimierzem Moczarskim rozmawia Mieczysław Orski, „Odra” 1974, nr 4, s. 81.

${ }^{9}$ Por. Anna Machcewicz, Kazimierz Moczarski. Biografia, Kraków: Znak, 2009, s. 292-293.

${ }^{10} \mathrm{Ibidem}$, s. 294. Andrzej Krzysztof Kunert wspomina, że książkę próbował Moczarski wydać również w Ossolineum. Zob. Andrzej Krzysztof Kunert, Oskarżony Kazimierz Moczarski, Warszawa: Iskry, 2006, s. 141.

${ }^{11}$ Cyt. za: Machcewicz, Kazimierz Moczarski..., s. 295.

${ }^{12}$ Kazimierz Moczarski, Rozmowy z katem, „Polityka” 1968, nr 26, s. 11. 
interpretację podpowiada zresztą sam tekst, skomponowany na kształt klasycznej biografii postaci - od jej urodzin po śmierć.

Właściwy debiut Rozmów z katem miał natomiast miejsce w „Odrze”. W numerze 4. z 1972 r. opublikowano wprowadzenie Andrzeja Szczypiorskiego pt. Kazimierza Moczarskiego rozmowy z katem. Był to pierwszy, dość złagodzony - również na skutek ingerencji cenzury, która usunęła cytat z rehabilitacyjnego wyroku sądowego - szkic na temat całości ${ }^{13}$. W numerze tym zamieszczono ponadto pierwsze dwie (z dwudziestu sześciu) relacji Moczarskiego, tj. Oko w oko ze Stroopem ${ }^{14}$ oraz U stóp Bismarckowego Cheruska ${ }^{15}$. Odtąd każdy kolejny numer „Odry” drukował po dwie, później zaśl ${ }^{16}$ jedną opowieść. Ostatnie dwie części (Zdjął czapkę skutymi rękami oraz Epilog) ukazały się w numerze 2. z 1974 r. ${ }^{17}$ Dwa numery później opublikowano dodatkowo wywiad Moczarskiego z Orskim pt. Jak powstały Rozmowy z katem ${ }^{18}$.

Przede wszystkim trzeba podziwiać odwagę „Odry” za podjęcie decyzji, by opublikować blisko czterystustronicową historię, której autor blisko jedenaście lat spędził w stalinowskim więzieniu, a później (w lipcu 1967 r.) został odwołany z kolegium redakcyjnego „Kuriera Polskiego” za antypaństwową postawę (Moczarski zajął krytyczne stanowisko względem nagonki antysemickiej) ${ }^{19}$. Ówczesny redaktor naczelny „Odry”, Zbigniew Kulikowski, przypłacił zresztą publikację Rozmów i późniejszego Zdażyć przed panem Bogiem ${ }^{20}$ dymisją. Jak wspomina Hanna Krall, został on wyrzucony „za całokształt, ale przede wszystkim za dwie rzeczy: za Moczarskiego i za Edelmana"21.

Sam tekst Rozmów opublikowanych w „Odrze” różnił się jedynie drobnymi szczegółami od tego, który ukazał się w roku 1977 w formie książkowej. Przede wszystkim wersję książkową pozbawiono wielu zdjęć, które w „Odrze” pełniły niezwykle ważną funkcję sensotwórczą ${ }^{22}$. Ponadto w książce zmieniono tytuły niektórych

${ }^{13}$ Zob. Andrzej Szczypiorski, Kazimierza Moczarskiego rozmowy z katem, „Odra” 1972 , nr 4, s. 14-15.

${ }^{14}$ Ibidem, s. $16-20$.

${ }^{15}$ Ibidem, s. 20-28.

${ }^{16}$ Od numeru 11. z 1972 r. Był to rozdział pt. „Już był w ogródku...” na Kaukazie. Zob. „Odra” 1972, nr 11, s. 17-21.

${ }^{17}$ Zob. „Odra” 1974, nr 2, s. 28-36.

${ }^{18}$ Jak powstawaty „Rozmowy...

${ }^{19}$ Zob. Kunert, Kazimierz Moczarski (1907-1975), s. 80-83.

${ }^{20}$ Pierwsza z rozmów ze Zdążý przed panem Bogiem ukazała się w „Odrze” w numerze 3. z 1975 r., kolejne opublikowano w roku 1976, nr 4-7/8.

${ }^{21}$ Cyt. za: A. Kuligowska-Korzeniowska, Zagłada na scenie. Dejmkowska inscenizacja „Zdażyć przed Panem Bogiem” Hanny Krall [w:] Pamięć Shoah. Kulturowe reprezentacje i praktyki upamiętnienia, red. Tomasz Majewski, Anna Zeidler-Janiszewska, Łódź: OFFicyna, 2009, s. 830.

${ }^{22}$ Na przykład w najbardziej chyba okrojonym w stosunku do późniejszych wydań książkowych tekście pt. Porcja ołowiu w amerykański kark („Odra” 1974, nr 1, w książce rozdział pt. Mord na amerykańskich lotnikach) znalazły się fotografie z artykułów pochodzących z „The Stars and Stripes”, które później usunięto. 
rozdziałów ${ }^{23}$, wprowadzono drobne poprawki stylistyczne, gdzieniegdzie zmieniono też czas z przeszłego na teraźniejszy ${ }^{24}$. Ogólnie późniejsze poprawki zmierzały w kierunku uczynienia narracji bardziej dobitną i bezpośrednią. Warto jednak zauważyć, że zapoznawanie się z cyklem tekstów, w odróżnieniu od czytania książki, implikuje nieco odmienny odbiór - z zasady mniej całościowy ${ }^{25}$.

Zarówno publikację w „Odrze”, jak i książkową w PIW wsparło wiele osób. Władysław Bartoszewski wspominał: „Moja żona, Zofia Bartoszewska, wtedy zastępca redaktora naczelnego PIW-u, czyniła usilne starania o zgodę na wydanie tej książki. Uwieńczone to zostało spóźnionym powodzeniem, bo Kazimierz Moczarski odszedł w świadomości, że książka będzie najpewniej wydana, ale faktu tego nie doczekał"26. Moczarski zmarł 27 września 1975 r. Ostateczną korektą książki zajęła się jego żona Zofia, która podobnie jak Moczarski spędziła sześć lat (od 1949 do 1955 r.) w więzieniu, i również nie doczekała jej sukcesu²7. Wkrótce po śmierci autora „Odra” opublikowała tekst, który stanie się kanonicznym odczytaniem Rozmów z katem na wiele lat. Mowa o Ukrytych siłach historii Franciszka Ryszki ${ }^{28}$, dołączonych jako wstęp do pierwszych książkowych wydań relacji Moczarskiego.

\section{„Jürgen Stroop był hitlerowcem typowym"29. Rozmowy w PIW}

Decyzja o opublikowaniu w kolejnych wydaniach PIW ${ }^{30}$ wstępu autorstwa Franciszka Ryszki była znacząca. Ryszka - prawnik, historyk i politolog, profesor Uniwersytetu Warszawskiego i Instytutu Historii PAN, lecz również Wojskowej

${ }^{23}$ Na przykład Na zapleczu z „Odry” 1972, nr 10 zamieniono w Na ,tytowym” froncie (rozdział XI książki), a Mord na feldmarszatku von Kluge („Odra” 1973, nr 11) na Stroop likwiduje feldmarszałka (rozdział XXIII).

${ }^{24}$ Na przykład fragment: „Stroop milczy chwilę. Zmienia się na twarzy. Patrzy to w okno, to na Schielkego, to na mnie. W końcu, mrugając oczyma o kolorze rybio-niebieskim, potakuje głową” (RzK, s. 292), w „Odrze” poprowadzony był w czasie przeszłym: „Stroop milczał chwilę. Zmienił się na twarzy...”. Por. „Odra” 1973, nr 6, s. 26.

${ }^{25}$ Wspomina o tym Jerzy Holzer, który pisząc po ukazaniu się książki o tekstach z „Odry”, zauważył: „Już wówczas budziły ogromne zainteresowanie, choć czytanie tego rodzaju tekstu we fragmentach, co miesiąc przez niemal dwa lata, utrudniało ogarnięcie go w całości. Trudno więc było zdać sobie sprawę z wyjątkowości publikacji Moczarskiego”. Zob. idem, Relacja z obcego świata, „Kultura” 1977, nr 26, s. 4-5.

${ }^{26}$ Władysław Bartoszewski, Mój Moczarski [w:] Kunert, Oskarżony..., s. VIII-IX.

${ }^{27}$ Zofia Moczarska zmarła 1 X 1977 r. i - jak wspomina córka Moczarskich - spowodowane to było właśnie pracami nad książką, które pochłonęły resztę jej poważnie nadwątlonych przez stalinowskie śledztwo (po wyjściu z więzienia miała kilka operacji, anemię, wreszcie raka płuc) sił . Zob. Po zamknięciu bramy więzienia. Rozmowa z Elżbieta Moczarska, córka autora „Rozmów z katem”, „Przegląd Tygodniowy” 1993, nr 51-52, s. 5.

${ }^{28}$ Franciszek Ryszka, Ukryte sity historii, „Odra” 1976, nr 2, s. 84-86.

${ }^{29}$ Idem, Przedmowa [w:] Kazimierz Moczarski, Rozmowy z katem, Warszawa: PIW, 1983, s. 8 .

${ }^{30}$ Przypominam, że było to pięć wydań w latach: 1977, dwa w 1978, 1983 i 1985. 
Akademii Politycznej - był w owym czasie uznanym autorem prac poświęconych faszyzmowi i historii Niemiec hitlerowskich ${ }^{31}$. Dobór takiego akurat autora wstępu podpowiadał zresztą sam Moczarski, gdy wyraźnie podkreślał, że sytuację umieszczenia ze Stroopem w jednej celi od początku wykorzystywał do odpowiedzenia sobie na pytanie: „jaki mechanizm historyczny, psychologiczny, socjologiczny doprowadził część Niemców do uformowania się w zespół ludobójców, którzy kierowali Rzeszą i usiłowali zaprowadzić swój Ordnung w Europie i w świecie” (RzK, s. 30). Swoje zadanie postrzegał więc jako badawcze - dotrzeć do sedna faszyzmu.

Ten przede wszystkim wątek wyeksploatował historyk, który uznał Rozmowy z katem za „wyższą rangę historycznego źródła, i to w dziedzinie studiów nad fenomenem faszyzmu, szczególnie w historiografii światowej ubogich, acz szczególnie ważnych”32. O samym zaś Moczarskim Ryszka napisał, że „znalazł w sobie tyle hartu i tyle autentycznej pasji poznawczej, że starał się nie tylko dociec motywów zbrodni swego współlokatora z celi, ale także dowiedzieć się, dlaczego, z jakich pobudek i w jakich okolicznościach stał się on hitlerowcem, i wreszcie, czemu zawdzięczał błyskotliwą karierę”. W tym celu:

przyjął jedynie słuszną zasadę poznawczą, fundamentalną dla marksistowskiej wykładni dziejów. Opinie i postawy polityczne - wedle tej wykładni - są przede wszystkim („w ostatniej instancji”) determinowane s p o ł e c z n i e [podkreślenie Franciszka Ryszki]. Środowisko, czyli jego normy ideowe i kulturowe, jego obyczaj i jego tradycja skłaniają do działań politycznych, decydują o wyborze drogi w takim, a nie innym kierunku ${ }^{33}$.

Reasumując, Kazimierz Moczarski staje się w tej wykładni badaczem-historykiem, który „nie myli się nawet w drobnych szczegółach co do dat i informacji geograficznych. Jego zapis jest dokładny i sumienny, zgadza się co do joty z aktualnym stanem wiedzy historycznej"34. Wszystko to sprawia, że jego wizerunek Stroopa jako typowego nazisty jest w pełni wiarygodny, podobnie jak przekazane przez Moczarskiego cechy: „swoiste pojęcie «rycerstwa», będące w istocie hołdowaniem przemocy i brutalności oraz przywiązaniem do anachronicznych wartości społeczno-towarzyskich, absolutną pogardę dla słabszych i respekt wobec siły”, połączoną z podstawowym wzorcem, którym był „stereotyp pruskiego oficera”35. Większą część przedmowy poświęca więc Ryszka Stroopowi. To z jego perspektywy widziana jest również Zagłada w symptomatycznym akapicie:

${ }^{31}$ Przed napisaniem tekstu w „Odrze” opublikował między innymi książki: Noc i mgła. Niemcy w okresie hitlerowskim (wyd. 1 1962), U źródeł sukcesu i klęski. Szkice z dziejów hitleryzmu (1972) oraz Państwo stanu wyjątkowego. Rzecz o systemie państwa i prawa Trzeciej Rzeszy (1964, wyd. 2 zmienione 1974).

${ }^{32}$ Ryszka, Przedmowa, s. 5.

${ }^{33}$ Ibidem, s. 6.

${ }^{34}$ Ibidem, s. 7.

${ }^{35}$ Ibidem, s. 8. 
Jürgen Stroop, sprawca licznych zbrodni wojennych i zbrodni przeciwko ludzkości, przejdzie przede wszystkim do ciemnych kart historii jako niszczyciel warszawskiego getta i masowy morderca jego mieszkańców. Tej karty życiorysu Stroop zresztą nie ukrywa. Epizod z likwidacją warszawskiego getta, za co polski sąd skazał go na śmierć, mieści się logicznie w zespole wyobrażeń i zbrodniczych celów systemu, odpowiada więc osobowości jego wiernego sługi. Podstawą tego jest konstrukcja wroga, którego musi się [podkreślenie Ryszki] zniszczyć. U jej podłoża legła swoista wersja drobnomieszczańskiego antysemityzmu, utkana ze stereotypów i przesądów ${ }^{36}$.

Stroop jest w tym ujęciu reprezentantem pewnej grupy społecznej i jej intersubiektywnych cech. Mamy tu więc do czynienia z ujęciem wspólnotowym, w którym fascynujące historyków lat pięćdziesiątych sylwetki katów zastąpiły metafory ponadjednostkowego aparatu biurokratycznego. Ujmując rzecz inaczej - opartą głównie na relacjach z procesów nazistów książkę The Final Solution Geralda Reitlingera ${ }^{37}$, w której głównymi bohaterami byli „skazywani” (ich życiorysy ${ }^{38}$, a nierzadko nawet wygląd ${ }^{39}$ ), wyparła monumentalna The Destruction of the European Jews Raula Hilberga $^{40}$, stanowiąca ujęcie socjologizujące, mniejszą wagę przywiązujące do osobistych inicjatyw Hitlera czy poszczególnych osób. W obu jednak ujęciach głównym przedmiotem zainteresowania są kaci, a nie ich ofiary. Tendencjom tym ulegają również inni polscy historycy tego czasu, na przykład Artur Eisenbach w Hitlerowskiej polityce zagłady Żydów ${ }^{41}$ czy Czesław Madajczyk w Polityce III Rzeszy w okupowanej Polsce $^{42}$. W nurt ten wpisuje się również Ryszka, nawet jeśli zastrzega, że przyjęcie

${ }^{36}$ Ibidem, s. 9.

${ }^{37}$ Gerald Reitlinger, The Final Solution. The Attempt to Exterminate the Jews of Europe, 1939-1945, London: Beechhurst Press, 1953.

${ }^{38}$ Dzieje się to na przykład przy przedstawianiu komendanta obozu Auschwitz-Birkenau Rudolfa Hössa, por. ibidem, s. 107-108.

${ }^{39}$ Zob. na przykład: „Globocnik’s personal appearance was physically good but the eyes and mouth were both shifty and brutal [Globocnik dobrze wyglądał pod względem fizycznym, ale miał rozbiegane oczy i poruszające się nerwowo usta, co nadawało jego twarzy brutalny wyraz]" (ibidem, s. 246).

${ }^{40}$ Ta trzytomowa książka ukazała się po raz pierwszy w $1961 \mathrm{r}$. nakładem małej oficyny Quadrangle Book w Chicago, Illinois, a od lat osiemdziesiątych zaczęła się spotykać z rosnącym zainteresowaniem zagranicznych edytorów. Obecnie w Centrum Badań nad Zagładą Żydów przy IFiS PAN trwają prace nad polskim wydaniem tej fundamentalnej monografii pt. Zagłada Żydów europejskich.

${ }^{41}$ Artur Eisenbach, Hitlerowska polityka zagłady Żydów, wyd. 2, Warszawa: Książka i Wiedza, 1961. Pierwsze wydanie tej książki nosiło tytuł Hitlerowska polityka eksterminacji Żydów w latach 1939-1945 jako jeden z przejawów imperializmu niemieckiego, Warszawa: ŻIH, 1953. Taki dobór tytułu związany był z szerzoną propagandą, w której przedstawiano Niemiecką Republikę Federalną (ta nazwa państwa niemieckiego - Republiki Federalnej Niemiec - obowiązywała oficjalnie w PRL do podpisania polsko-niemieckiego układu z 1970 r.) jako kontynuatorkę polityki Trzeciej Rzeszy.

${ }^{42}$ Czesław Madajczyk, Polityka III Rzeszy w okupowanej Polsce, t. 1-2, Warszawa: PWN, 1970. 
takiej optyki „grozi nam [...] depersonalizacją zbrodni”, a „ci, co wydali rozkaz zburzenia warszawskiego getta i wymordowania resztek jego mieszkańców, autorzy i wykonawcy planu «Grossaktion Warschau», to nie były kółka wielkiej maszynerii. Byli to żywi ludzie, uformowani przez swoją historię, swoją kulturę, swoje otoczenie, wdrażani stopniowo, lecz bez zahamowań, do zbrodni”43.

Poświęcone oprawcy - tyleż osobie z krwi i kości (Reitlinger), ile przedstawicielowi pewnej grupy (Hilberg) - Rozmowy z katem Moczarskiego mogły zadowolić rozmaitych odbiorców, trafiły więc na podatny grunt. Książka błyskawicznie zniknęła z księgarni ${ }^{44}$. Nie może też dziwić wyjątkowo pozytywna jej recepcja (wśród omówień Rozmów nie spotkałem negatywnej opinii!), towarzysząca książce od samego początku. Większość recenzji zwracała uwagę na podobne aspekty opowieści Moczarskiego.

Jeden z pierwszych pisał o książce Kazimierz Koźniewski, nazywając Stroopa „fanatycznym przeciętniakiem, dewotem hitleryzmu”45, w duchu modernistycznych historyków dodając dalej:

bredzono na temat odwiecznego ducha germańskiego, który jakoby Hitlerowi ułatwił działanie. Nie wierzę w te duchy narodowe. Wierzę natomiast w okoliczności społeczne, polityczne, gospodarcze, które sprawiały, że nagle byle jaki Jürgen Stroop, półinteligent, ćwierćurzędnik z 1600-tysięcznego księstwa Lippe, staje się twórczym i czynnym SS-manem. Nikt nie był przed faszyzmem zabezpieczony! Ci tylko, którym faszyzm wojnę wypowiedział lub oni mu wojnę świadomie wypowiedzieli ${ }^{46}$.

Swoje omówienie Koźniewski zamknął prośbą do wydawców o wspólną edycję „w jednej, nawet dwutomowej księdze - pamiętnika Rudolfa Hoessa i rozmów z Jürgenem Stroopem”47. Owo zestawienie, poszukujące podobieństw w psychice obu postaci nazistów oraz ich wspólnych zainteresowaniach (np. miłości do koni), będzie się odtąd w wypowiedziach na temat Rozmów z katem pojawiało regular$n^{4}{ }^{48}$. Koźniewski nie dostrzegał w ogóle Holokaustu i kwestii żydowskiej w opowieści Moczarskiego. Główny jego niepokój budził natomiast brak pytań (i odpowiedzi Stroopa) o wrzesień 1939 r. Autor Piątki z ulicy Barskiej poruszył ten wątek w recenzji dwukrotnie.

W tym samym co Koźniewski kierunku poszli następni. Kazimierz Nowosielski zauważył, że „nie rytm życia i rozmów w celi jest osią konstrukcyjną książki.

\footnotetext{
${ }^{43}$ Ryszka, Przedmowa, s. 11.

44 „Przed kilkoma miesiącami PIW wydał książkę Kazimierza Moczarskiego pt. Rozmowy z katem. Dzisiaj książka ta, mimo iż minęło od jej publikacji zaledwie pół roku - w księgarniach jest nieosiągalna, a w antykwariatach trzeba płacić za nią setki złotych" - pisał w grudniu 1977 r. Zdzisław Umiński. Zob. idem, Stroop, „Kierunki” 1977 nr 48, s. 12.

${ }^{45}$ Kazimierz Koźniewski, Sceny więzienne szekspirowskie, „Literatura” 1977, nr 27, s. 3.

${ }^{46}$ Ibidem.

${ }^{47}$ Ibidem.

${ }^{48}$ Najkonsekwentniej porównanie Höessa i Stroopa prowadzi Stanisław Zieliński. Zob. idem, Mokotów 1949, „Nowe Książki” 1977, nr 14, s. 40-41.
} 
Moczarski wymija nasze oczekiwania, rdzeniem relacji czyniąc koleje życia samego Stroopa, tak jak one wyłaniały się z pozornego czy rzeczywistego bezładu dialogu [...] podobnie jak Tadeusz Borowski, bardziej niż człowieka zdaje się oskarżać kulturę, która go kształtuje”, a „rozmowy z katem stają się esejem o sposobie istnienia systemu totalitarnego" ${ }^{49}$. Z kolei Aleksander Małachowski pisał, że „rzetelność relacji Moczarskiego co do faktów i opisów potwierdza w przedmowie znany historyk Franciszek Ryszka”, samą książkę należy zaś zaliczyć do „ważnych dokumentów epoki hitleryzmu”, ponieważ „zawsze żywa pozostanie opowieść o tym, jak człowiek staje się zbrodniarzem" ${ }^{0}$. Wyłącznie o wizerunku Stroopa - z drobnym odstępstwem na rzecz refleksji o brakach w opisie Schielkego - pisze Jerzy Holzer, podkreślając, że „rejestruje Moczarski cechy osobowości autorytarnej w sposób niemal podręcznikowy"51. Jedynie sylwetką Stroopa zajmował się również Krzysztof Nowicki w Zwierzeniach ludobójcy. Krytyk zwracał uwagę, że wszelkie autorskie emocje „zostały podporządkowane celowi nadrzędnemu: dowiedzieć się jak najwięcej, określić mentalność ludobójcy, jego poziom umysłowy, wniknąć w coś, co zastępuje jego życie duchowe” 52 . W rezultacie „Przed naszymi oczami rodzi się obszerny obraz kariery ludobójcy. Śledzimy koleje jego partyjnych awansów i wtajemniczeń. Poznajemy fakty”33.

Bodaj najwyraźniej rolę książki Moczarskiego w przedstawianiu faszyzmu uwypuklił Krzysztof Teodor Toeplitz, wskazując, iż z Pamiętników Hoessa poznaliśmy psychologiczny fenomen technicyzacji zbrodni, ze Wspomnień Alberta Speera „poszukiwanie mocy” i kult siły, z Dzienników Hansa Franka zaś „zimną buchalterię biurokracji”. Teraz do tej listy możemy dołączyć jeszcze Rozmowy ze Stroopem, które ujawniają „niewydobyty dotą tak jasno na światło dzienne motyw - instynkt ferajny”, a więc potrzebę bycia wśród ludzi, po których stronie jest władza i siła. Chęć, by ci ludzie, których się Stroop bał, „uważali go za swego”54.

Jedynym, który w tym czasie zauważył, że książka Moczarskiego opowiada również o cierpieniu Żydów, był Gustaw Herling-Grudziński, a uczynił to na łamach publikowanego w „Kulturze” paryskiej Dziennika pisanego noca. Uzupełnił on pogląd, że „Rozmowy z katem Moczarskiego są książką niebywałą, przewyższającą chwilami Eichmanna w Jerozolimie Hanny Arendt”55, konstatacją, iż pełny obraz książki da nam dopiero zrozumienie męki tych, którzy tkwili w stalinowskich więzieniach. Zdaniem Herlinga, książkę Moczarskiego trzeba wydać w przyszło-

\footnotetext{
${ }^{49}$ Kazimierz Nowosielski, Reportaż z oddziału XI, „Twórczość” 1977, nr 11, s. 123-124.

${ }^{50}$ Aleksander Małachowski, Rozmowy z katem, „Odra” 1978, nr 2, s. 97 i 99.

${ }^{51}$ Holzer, Relacja z obcego świata.

${ }^{52}$ Krzysztof Nowicki, Zwierzenia ludobójcy [w:] idem, Dziennik krytyczny, Gdańsk: Krajowa Agencja Wydawnicza, 1981, s. 135.

${ }^{53}$ Ibidem, s. 136.

${ }^{54}$ KTT [Krzysztof Teodor Toeplitz], Instynkt ferajny, „Kultura” 1977, nr 23, s. 16.

${ }^{55}$ Gustaw Herling-Grudziński, Dziennik pisany noca, „Kultura” (Paryż) 1978, nr 10, s. 22 .
} 
ści razem z relacją Anieli Steinsbergowej Widziane z ławy obrończej56. Wypowiedź Herlinga będzie później często przywoływana w latach dziewięćdziesiątych.

W nieco inną stronę zmierzał natomiast Stefan Pełczyński, zwracając uwagę na fakt, że Franciszek Ryszka z racji swojego zawodu „zredukował pole widzenia i książkę oceniał w kategoriach literatury historycznej”, tymczasem można ją uznać za studium socjologiczne, psychologiczne, a nawet moralitet. W swej „najgłębszej istocie” jest to jednak opowieść literacka, a bohaterowie stanęli wobec wyjątkowej sytuacji, w której „nikt z nich jeszcze nie umarł, ale też nikt nie należał już do żywych" ${ }^{2}$. Ów czynnik sytuacyjny podkreślać będą recenzje ukazujące się po premierze Rozmów z katem w Teatrze Powszechnym w styczniu 1978 r. Pora, by poświęcić temu spektaklowi nieco miejsca.

\section{„Bohaterem głównym Rozmów z katem jest Stroop, bohaterem tragicznym - jest Moczarski"58. Rozmowy na deskach Teatru Powszechnego}

Rozmowy z katem na deskach Małej Sceny Teatru Powszechnego w Warszawie wyreżyserował Andrzej Wajda, za układ tekstu odpowiadał zaś Zygmunt Hübner, który również wcielał się w postać Kazimierza Moczarskiego. Partnerowali mu Stanisław Zaczyk, odgrywający rolę Stroopa, oraz Kazimierz Kaczor jako Schielke. Scenografię przygotował Allan Starski. Spektakl podzielony był na dwie części. W pierwszej Hübner-Moczarski odczytywał fragmenty aktu rehabilitacyjnego oraz wywiadu z Orskim. Sam aktor wspominał, że pewna część publiczności zadawała mu pytania, w przekonaniu, że jest Moczarskim ${ }^{59}$. Druga część była już odtworzeniem właściwego tekstu książki i rozgrywała się w znajdującej się na scenie celi. Premiera odbyła się 7 stycznia $1978 \mathrm{r}$.

Genezę przedstawienia dobrze wytłumaczyła, moim zdaniem, Małgorzata Szpakowska. Zwracała ona uwagę na dwie możliwe inspiracje - teatralną tradycję sięgania do rzeczywistości z powodu wyjałowienia konwencji dramatycznych oraz wagę samej książki-dokumentu, „którego publikacja miała sens nie tylko oskarżycielski, lecz również katartyczny. Bo ujawnienie prawdy o człowieku i historii zawsze jest oczyszczeniem"60. Decyzja o tak szybkiej adaptacji wydanej dopiero książki z pewnością przyczyniła się do wzmocnienia rezonansu, jaki wywołały Rozmowy. Nie

${ }^{56}$ Aniela Steinsbergowa była adwokatem w procesie rehabilitacyjnym Moczarskiego. Widziane $z$ ławy obrończej to zapis jej wrażeń z tego procesu. Zob. eadem, Widziane $z$ ławy więziennej, Paryż: Instytut Literacki, 1977. Książka Steinsbergowej była również wielokrotnie przedrukowywana w drugim obiegu.

${ }^{57}$ Stefan Pełczyński, Przy drzwiach zamkniętych, „Miesięcznik Literacki” 1978, nr 1, s. 136.

${ }^{58}$ Marta Fik, Paradoks autentyzmu, „Polityka” 1978, nr 4, s. 9.

${ }^{59}$ Zygmunt Hübner, Zamiast życiorysu [w:] Zygmunt Hübner. 23 marca 1930-12 stycznia 1989, Gdańsk-Kraków-Warszawa: Teatr Wybrzeże i in., 2000, s. 8.

${ }^{60}$ Małgorzata Szpakowska, Dobre samopoczucie Jürgena Stroopa, „Dialog” 1978, nr 4, s. 137. 
bez znaczenia było również miejsce wystawienia - Mała Scena Teatru Powszechnego. Michał Misiorny pisał na łamach „Trybuny Ludu”:

Teatr Powszechny obrał adaptację tej książki jako tworzywo kolejnej premiery na Małej Scenie, traktowanej niekiedy jako podium publicystyczne. W istocie bowiem Rozmowy z katem nie zapowiadają sztuki teatru i teatrem nie są. Jest to raczej lekcja zawikłanego fragmentu historii, połączona z próbą rekonstrukcji portretu psychologicznego zbrodniarza ${ }^{61}$.

Większość recenzentów spektaklu podkreślała, że doszło w przedstawieniu do pewnego przesunięcia akcentów w stosunku do narracji książki. Małgorzata Szpakowska ujęła to następująco:

Przedstawienie w Teatrze Powszechnym jest przedstawieniem przede wszystkim o Moczarskim, nie o Stroopie. Albo inaczej: jest opowieścią o warunkach powstawania książki Moczarskiego, nie jego inscenizacją. Wynika to z kilku powodów, z których najbardziej oczywisty jest zarazem decydujący. Po prostu: spektakl jest unaocznieniem pewnej sytuacji, celę i skazanych w i d z i m y [podkreślenie Małgorzaty Szpakowskiej], gdy opowieści, choćby najbardziej wstrząsające, pozostają tylko opowieściami ${ }^{62}$.

Wtórowała jej Marta Fik, zwracając uwagę, że spektakl wydobył drugą warstwę książki, niezmiernie istotną. „Idzie o samą sytuację, w której do zwierzeń doszło” - pisała ${ }^{63}$. Dalej Fik jednak podkreślała, że wprawdzie przedstawienie jest osiągnięciem ambitnym i odważnym, ale „Moczarski silniej przemawia z kart książki, nie ze sceny [...] ze względu na pewne prawa rządzące teatrem" ${ }^{64}$. Z kolei Roman Szydłowski stwierdzał, iż Zygmunt Hübner i Andrzej Wajda „zaprezentowali ascetyczne widowisko dokumentarne, epicki teatr polityczny”, dodając, że był w Warszawie „owej Wielkiej Nocy, kiedy płonęło getto” i kiedy słuchał „suchej, rzeczowej relacji Jürgena Stroopa”, odżyły w nim wspomnienia ${ }^{65}$.

Ciekawa jest również recenzja Krzysztofa Kąkolewskiego, który wspomina, że pierwszy raz znalazł się w roli recenzenta teatralnego, poproszony przez redakcję „Teatru” o spostrzeżenia na temat spektaklu ${ }^{66}$. Kąkolewski notował: „W książce Moczarski ukazuje pseudoromantyczną, krwawą i piękną we wspomnieniach Stroopa historię hitleryzmu. W spektaklu Wajda i Hübner oddają nastrój celi więziennej,

\footnotetext{
${ }^{61}$ Michał Misiorny, Spotkanie w celi, „Trybuna Ludu” 1978, nr 39, s. 8.

${ }^{62}$ Szpakowska, Dobre samopoczucie Jürgena Stroopa, s. 138.

${ }^{63}$ Fik, Paradoks autentyzmu, s. 9.

${ }^{64}$ Ibidem.

${ }^{65}$ Roman Szydłowski, Przed sądem historii, „Życie Literackie” 1978, nr 8, s. 6.

${ }^{66}$ Krzysztof Kakolewski opublikował w 1975 r. w warszawskim Czytelniku Co u Pana stychać - zbiór wywiadów przeprowadzonych z byłymi wojskowymi, naukowcami i funkcjonariuszami Trzeciej Rzeszy. Stąd autor mógł napisać, że jest „drugim poza Kazimierzem Moczarskim Polakiem, który po 1 IX 1939 r. rozmawiał z generałami SS - po to tylko, by z nimi rozmawiać - a nie jako przesłuchiwany lub przesłuchujący”. Zob. idem, Żotnierz w szarym garniturze, „Teatr” 1978, nr 7, s. 4.
} 
w której wrogowie znaleźli się oko w oko"67. Podobnie jak Szpakowska i Fik, autor Co u pana stychać podkreślał też, że podstawową różnicą w stosunki do książki jest widoczna obecność samego Moczarskiego:

Moczarski chciał napisać książkę o Stroopie. Przez skromność usuwał się w cień, spychał na margines, czyniąc z siebie tylko medium, katalizator zwierzeń Stroopa. A jednak - wbrew Moczarskiemu - jest to spektakl również o Moczarskim, jego postawie wobec niesprawiedliwości i krzywdy, o znalezieniu siły, by wykorzystać ją dla siebie, dla narodu. Hübner staje się na naszych oczach Moczarskim, przeistacza się w niego, w przyciszeniu i uśmiechu ukrytym w głosie, nawet $z$ takim samym sposobem noszenia szaroniebieskiego ubrania, ponieważ Moczarski był żołnierzem, który nigdy nie nosił munduru ${ }^{68}$.

Wątpliwości Kąkolewskiego wzbudziła natomiast kreacja Kaczora, ponieważ Schielke w jego interpretacji staje się - zdaniem krytyka - „polskim cwaniaczkiem"69.

Pomijając jednak to drobne przesunięcie znaczeń, nie ulega wątpliwości, że odczytania Rozmów z katem w latach siedemdziesiątych i osiemdziesiątych zdominowała rekonstrukcja wizerunku Stroopa. Co ważniejsze, zajmując się katem, zajmowano się nazizmem i jego mechanizmami, nie dostrzegając, że kulminacyjna część książki Moczarskiego poświęcona jest Zagładzie. Ta zresztą - jako pewien problem - jest zasadniczo w tych latach w polskim dyskursie nieobecna ${ }^{70}$. Dyskurs o Holokauście pojawi się dopiero wtedy, gdy jego istnienie stworzy dla innych dyskursów problem - gdy będą musiały go wchłonąć lub odrzucić, gdy będą musiały się jakoś względem niego określić. Przyjrzenie się ofiarom oznaczać będzie początek zainteresowania Zagładą w Polsce, która jako przedmiot refleksji zacznie tu być podejmowana od drugiej połowy lat osiemdziesiątych, wraz z emisją w telewizji publicznej Shoah Lanzamanna (1985), opublikowaniem w „Tygodniku Powszechnym” eseju Jana Błońskiego Biedni Polacy patrza na getto (1987) czy obchodami czterdziestej

\footnotetext{
${ }^{67}$ Ibidem.

${ }^{68}$ Ibidem, s. 4-5.

${ }^{69}$ Ibidem.
}

${ }^{70}$ Nie oznacza to oczywiście, że w ogóle się w owym czasie nie pisze. Z ważniejszych literackich tekstów wymienić można następujące publikacje: Mała księga Kazimierza Brandysa (Warszawa: Czytelnik 1970), Niezwykła podróż doktora Friede Stanisława Murzańskiego (Warszawa: Pax, 1970), Chleb rzucony umartym Bogdana Wojdowskiego (Warszawa: PIW, 1971), Nie było słońca tej wiosny Jerzego Ofierskiego (Warszawa: Czytelnik, 1972) Szczurzy pałac Bogdana Ruthy (Kraków: Wydawnictwo Literackie, 1973), Zdązyć przed panem Bogiem Hanny Krall (Kraków: Wydawnictwo Literackie, 1977) oraz Opowiadanie $z$ Worochty Kazimierza Wyki (z tomu Opowiadania, Kraków: Wydawnictwo Literackie, 1978). Zagłada pojawia się również w postaci zawoalowanej paraboli w Mszy za miasto Arras Andrzeja Szczypiorskiego (Warszawa: Czytelnik, 1971) czy przemyconym rok później w „Literaturze” opowiadaniu Wielbłąd Kazimierza Orłosia („Literatura” 1972, nr 45-46). 
piątej rocznicy powstania w getcie warszawskim $(1988)^{71}$. Ważna okazała się również zmiana pokoleniowa, którą podsumował Michael Steinlauf:

Zainteresowanie to [Żydami, judaizmem i przeszłością Żydów w Polsce] rozbudziło się przede wszystkim w pokoleniu powojennym, które ani nie widziało „prawdziwego Żyda”, ani nie było świadkiem Zagłady. Pokolenie to, wychowane w monochromatycznym świecie kulturalnej i etnicznej jednorodności, przesiewało polską przeszłość, aby odkryć różnorodność i wielobarwność. Młodzi ludzie odkrywali więc obraz brodatego, ubranego na czarno Żyda - wyjątkowo egzotycznego, a przecież niepamiętanego sąiada, osadzonego w przedwojennym krajobrazie Polski, której podobnie jak Żyda, też już nie było ${ }^{72}$.

Łabędzim śpiewem interpretacji totalitarnej, a zarazem zalążkiem nowych możliwości, jakie pojawiły się przed interpretatorami, którzy zaczęli dostrzegać rolę odgrywaną w narracji przez Holokaust, są dydaktyczne propozycje Andrzeja Łopaty. Mogły się one stać u progu lat dziewięćdziesiątych pewnym kamieniem granicznym. Łopata podkreślał, że „wszechstronna charakterystyka sylwetki Jürgena Stroopa powinna być częścią zasadniczą lekcji lub nawet wypełnić może całą lekcję"73, wszelako zauważył zarazem, że „Rozmowy z katem stanowią dokładny opis przebiegu Wielkiej Akcji”, w dodatku „tekst Moczarskiego wniósł coś zupełnie nowego: relację z punktu widzenia sprawcy"74. Okazało się jednak, że interpretatorzy książki Moczarskiego w tej dekadzie wybrali trzecią - poza nazizmem i Zagładą - drogę.

\section{„Poznając zakamarki duszy Stroopa, Moczarski szukał pośrednio wiedzy o swych prześladowcach"75. Rozmowy w PWN}

Kolejne wydania Rozmów z katem ukazują się już w nowych realiach, zmienił się również ich odbiór. Zaczęto odtąd podkreślać inną kwestię, dotychczas marginalizowaną - więzienne cierpienie Moczarskiego. Losy autora były w samym tekście ukryte, pierwszym zabiegiem stało się więc ich ujawnienie, co też zrobiono w pierwszej edycji bez cenzury, czyli wydaniu PWN z 1992 r.

${ }^{71}$ Spośród wielu tekstów, które są poświęcone wyłonieniu się w połowie lat osiemdziesiątych dyskursu Zagłady w Polsce, na szczególną uwagę zasługuje książka Piotra Foreckiego, najszerzej omawiająca to zagadnienie. Zob. idem, Od Shoah do Strachu. Spory o polsko-żydowska przeszłość i pamięć $w$ debatach publicznych, Poznań: Wydawnictwo Poznańskie, 2010.

${ }^{72}$ Michael C. Steinlauf, Pamięć nieprzyswojona, tłum. Agata Tomaszewska, Warszawa: Cyklady, 2001, s. 120.

${ }^{73}$ Andrzej Łopata, Człowiek $i$ kat $w$ perspektywie historycznej $i$ uniwersalnej $w$ świetle powieści Kazimierza Moczarskiego „Rozmowy z katem”, „Język Polski w Szkole Średniej” 1990/1991, z. 3, s. 25.

${ }^{74}$ Ibidem, s. 26.

${ }^{75}$ Andrzej Szczypiorski, O Kazimierzu Moczarskim (RzK, s. 15). 
Wiele o nowych tendencjach interpretacyjnych mówi decyzja zamieszczenia w wydaniu PWN wstępu autorstwa Andrzeja Szczypiorskiego. Po raz pierwszy wstęp ten ukazał się już w 1978 r. w zachodnioniemieckim wydaniu Rozmów ${ }^{76}$. Opublikowany w Niemczech, został zresztą już wtedy zauważony. Zbigniew Ramotowski, korespondent „Życia Warszawy”, pisał, że tekst Szczypiorskiego objawia „antykomunizm i antyradzieckość, fałsz historyczny i nienawiść do tego wówczas nowego, jedynie słusznego, choć rodzącego się w bólach, państwa polskiego"77. Wstęp Szczypiorskiego został zaatakowany także przez Mieczysława Górę, który podkreślał w „Perspektywach”, że „autor owej przedmowy, Andrzej Szczypiorski, sprzeniewierzył się w niej nie tylko faktom historycznym, ale i dobremu imieniu Polski"78. Przede wszystkim zaś Ramotowski i Góra zarzucali Szczypiorskiemu, że potraktował Rozmowy jako pretekst i nie zajmował się głównym celem książki - opisaniem osobowości Stroopa, poświęcając się w zamian „tendencyjnemu, pełnemu przeinaczeń i fałszów przedstawianiu Polski Ludowej"79. Szczypiorski nie pozostał im dłużny. Odpowiedział Ramotowskiemu na łamach „Życia Warszawy”, iż jego tekst „pełen jest rozmaitych insynuacji”, natomiast on sam - zwolennik „wielopoglądowości i pluralizmu” - nie odmawia Ramotowskiemu „prawa do głoszenia jego poglądów”, ale równocześnie domaga się prawa głoszenia poglądów swoich. Ponadto Szczypiorski wytykał Ramotowskiemu, że nie zna własnej gazety, ponieważ znaczna część faktów pomieszczonych w przedmowie pochodzi właśnie z „Życia Warszawy" 80 .

Przedstawienie owej polemiki było konieczne, by naświetlić kontekst, w jakim ukazało się pierwsze wydanie Rozmów w III Rzeczypospolitej, opatrzone - przewrotnie - przedmową sprzed lat. Trzeba przyznać, że już od pierwszych słów przedmowy Szczypiorski nie pozostawia wątpliwości, na co położy główny nacisk:

Po zakończeniu II wojny światowej władzę w Polsce objął rząd komunistyczny. Wypełniając dyrektywy Stalina, podjął bezlitosną walkę z niezależnymi, narodowymi ośrodkami. Rozpoczęły się prześladowania żołnierzy i oficerów AK, którym udało się uniknąć śmierci z rąk Niemców. Więzienia zapełniły się najlepszymi i najdzielniejszymi bojownikami walk z nazistowską

\footnotetext{
${ }^{76}$ Kazimierz Moczarski, Gespräche mit dem Henker, Düsseldorf: Droste Verlag, 1978.

${ }^{77}$ Zbigniew Ramotowski, Spektakl ignorancji i złej woli. Nadreńskie „Rozmowy z katem”, „Życie Warszawy”, 17-18 XI 1979, s. 6.

${ }^{78}$ Mieczysław Góra, „Porządny Polak” pisze przedmowę..., „Perspektywy” 1979, nr 15, s. $17-18$.

${ }^{79}$ Ibidem, s. 18.

${ }^{80}$ Andrzej Szczypiorski, Do redaktora „Życia”. Spektakl ignorancji i złej woli, „Życie Warszawy” 1979, 26 XI, s. 6. W tym samym miejscu została również przedrukowana odpowiedź Ramotowskiego, który podtrzymał wszystkie swoje zarzuty. Szczypiorskiego broniono też na łamach czasopism podziemnych. Zob. na przykład Jacek Bierezin, Góra urodziła mysz, „Biuletyn Informacyjny” 1979, nr 3, oraz Moczarski, Szczypiorski i „Życie Warszawy”, „Zapis” 1980, nr 13. W drugoobiegowym „Pulsie” (1979, nr 6) przedrukowano ponadto sam wstęp z niemieckiego wydania Rozmów.
} 
przemocą. Niewiarygodna perfidia Stalina podsunęła mu pomysł, niepojęty dla ludzi wychowanych w normalnym, demokratycznym świecie. Uznał on za właściwe, by ludzi, którzy w szeregach AK walczyli z hitlerowskimi Niemcami, traktować jako sojuszników nazizmu. Oficjalna propaganda nazywała najlepszych patriotów faszystami i pachołkami Gestapo. Oskarżano ich o współpracę z wrogiem i zdradę narodu polskiego. Na podstawie sfabrykowanych oskarżeń skazywani byli na śmierć lub długoletnie więzienie. Procesy toczyły się w trybie niejawnym, a oskarżeni nie mieli prawa do obrony. Pod wpływem fizycznych i duchowych udręk wielu wybrało samobójstwo. Inni przyznawali się do niepopełnionych przestępstw, byle położyć kres cierpieniom. Ludzie ci przeszli przez piekło (RzK, s. 7).

Ton Szczypiorskiego bezbłędnie podchwycili również interpretatorzy. Kazimierz Masłoń na przykład, komentując PWN-owskie wydanie, pisał wyłącznie o Moczarskim. Przytaczając opinię Herlinga-Grudzińskiego, podkreślał też, że autor Rozmów był torturowany, wreszcie zauważył:

Wyrosło już nowe pokolenie czytelników, dla których Rozmowy z katem są legendą. Starsi też pewnie chętnie przypomną sobie tę książkę, już w pełnej wersji, z tymi jakże ważnymi dla wszystkich słowami Kazimierza Moczarskiego, który w zakończeniu Rozmów z katem, pisząc o swoim pobycie w więzieniu, stwierdzał: Podobne bytowanie sprzyja upartemu trzymaniu się zasad, a nie uleganiu okolicznościom i konieczności lawirowania, które łatwo się może przekształcić w lawiranctwo ${ }^{81}$.

Trzeba pamiętać o tym, że przez całe lata dziewięćdziesiąte książka Moczarskiego znajdowała się na liście licealnych lektur. W omówieniach lektury także podkreślano, że „stalinowski wymiar «sprawiedliwości» nazwał Moczarskiego zdrajca narodu” 82 oraz że „Rozmowy z katem są utworem o tyranii w ogóle i nie wolno odczytywać ich jako dzieła wyłącznie o hitleryzmie"83.

Ogólnie kata zastąpiła więc ofiara, Stroopa zastąpił Moczarski ${ }^{84}$. Zaczął się również proces społecznego gloryfikowania tego drugiego i podkreślania jego niezłomnej postawy wobec systemu komunistycznego. Wydawać się mogło, że z czasem owo binarne oscylowanie między Stroopem a stalinizmem się skończy. Okazało się jednak, że tendencje rozliczeniowe nie osłabły, z czasem zaczęły się wręcz nasilać.

${ }^{81}$ Krzysztof Masłoń, Bez cenzury i... bez korekty. Petne wydanie „Rozmów z katem” Kazimierza Moczarskiego, „Rzeczpospolita”, 1 XII 1992, s. 3. Masłoń wytyka również w swej recenzji błędy korektorskie (stąd tytuł). Rzeczywiście w tym wydaniu Moczarski zamienił się w Moczara, a XX Zjazd KPZR w XI. Zob. też DES, „Rozmowy z katem” - bez cenzury, „Trybuna” 3 XII 1992, s. 5.

${ }^{82}$ Paweł Stanisławski, Rozmowy z katem, „Biblioteczka Opracowań” nr 45, Lublin: Biblioteka Wysyłkowa, 1999, s. 6-7.

${ }^{83}$ Ibidem, s. 32.

${ }^{84}$ W 1994 r. Andrzej Titkow nakręcił film dokumentalny poświęcony Kazimierzowi Mocarskiemu pt. Na Hożej, Jasnej i Stonecznej. O pisarzu opowiadają w nim jego bliscy, przyjaciele, towarzysze broni i historycy. Titkow wykorzystał także fragmenty spektaklu oraz listy i dziennik pisarza. 


\section{„W polskiej rzeczywistości los Moczarskiego dobitnie ilustruje determinację powojennego reżimu kontrolowanego przez ZSRR"85. Rozmowy w Znaku}

W roku 2002 ukazała się kolejna edycja Rozmów w krakowskim wydawnictwie Znak. Opatrzono ją nowym wstępem, tym razem autorstwa Normana Daviesa. Nie zmienił on jednak dominującej, antykomunistycznej interpretacji. Pod pewnymi względami ją nawet wzmocnił. Ze wstępu Daviesa można się dowiedzieć - z grubsza - tego samego, co ze wstępu Szczypiorskiego: „Mimo iż Moczarski i jego współtowarzysze-akowcy z determinacją i poświęceniem walczyli z nazistami, komuniści bez wahania skazali go na karę śmierci jako kolaboranta" ${ }^{86}$. Przeczytać również możemy, iż „przez kilkanaście lat od przejęcia wpływów przez Sowietów w 1944 roku w Polsce panoszyły się brutalna siła i matactwo, a stery władzy trzymała grupka polityków bezwzględnie posłusznych rozkazom z Moskwy"87.

Podobnie interpretuje tę książkę Andrzej Krzysztof Kunert, pisząc w Oskarżonym Kazimierzu Moczarskim: „Rozmowy z katem były i są powszechnie uważane - nie tylko w Polsce, ale i na świecie (tłumaczone wszak na wiele języków) - za jedno z najważniejszych świadectw XX wieku. Tylko że w Polsce do końca istnienia PRL wolno było pisać o ogromnym ich znaczeniu jedynie dla poznania «socjologii ruchu hitlerowskiego», a wyłącznie poza krajem można było zwrócić uwagę na znacznie szerszy ich kontekst"88.

Ukoronowaniem podobnego odczytania Rozmów stało się przedstawienie Teatru Telewizji, w ramach tzw. Sceny Faktu. Rozmowy z katem zaadaptował na mały ekran Tadeusz Nyczek, wyreżyserował zaś Maciej Englert. Wyemitowane zostały w kwietniu 2007 r. Zgromadziły przy tym pokaźną widownię ${ }^{89}$. Rolę Stroopa grał Piotr Fronczewski, Moczarskiego Andrzej Zieliński, a Schielkego Sławomir Orzechowski. Novum i zarazem udosłownieniem przekazu było wprowadzenie sceny porwania przez ubeków oraz tortur w więzieniu - bicia, wymalowanego napisu „Gestapo” na czole Moczarskiego itp. Liczba występujących postaci w związku z tym się zwiększyła.

${ }^{85}$ Norman Davies, Wstęp [w:] K. Moczarski, Rozmowy z katem, oprac. Andrzej Krzysztof Kunert, Kraków: Znak, 2009, s. 7.

${ }^{86}$ Ibidem.

${ }^{87}$ Ibidem, s. 8.

${ }^{88}$ Kunert, Oskarżony..., s. 1.

89 „Rozmowy $z$ katem zdobyły milion trzysta pięćdziesiąt tysięcy widzów, zajmując w rankingu oglądalności jedenaste miejsce i piąte wśród premier tego sezonu. W grupie +4 [tj. wśród wszystkich widzów - B.K.] uzyskały 3,8 procent widowni przy udziałach 12,61 procent, a w grupie 16-49 lat aż 3,42 procent widowni przy udziałach na poziomie 12,1 procent, czyli gromadząc przed telewizorami blisko sześćset czterdzieści tysięcy widzów. Są najlepiej oglądanym spektaklem sezonu w tej grupie widzów, na co na pewno warto zwrócić uwagę" - pisała Kalina Zalewska. Zob. eadem, Scena Faktu w Teatrze Telewizji, „Dialog” 2007, nr 10, s. 98 . 
Podejrzliwie podeszły do tej realizacji Kalina Zalewska i Weronika Szczawińska. Pierwsza z nich, umieszczając spektakl Englerta na tle innych z cyklu „Scena Faktu”, podkreślała, że „jej bohaterami są z reguły ludzie pokrzywdzeni w minionym ustroju, a potem zazwyczaj przemilczani i zapomniani [...]. W tym sensie Scena Faktu odkrywa na nowo peerelowską historię i dlatego niemal wszystkie spektakle tego gatunku powstają we współpracy z historykami IPN-u"90. Druga zauważyła, że wprawdzie przedstawienie Englerta odróżnia się od pozostałych z tego cyklu mniejszą hagiograficznością, ale „z innymi przedstawieniami łączy je jednak pokre-

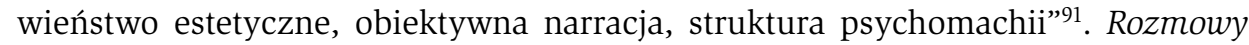
$z$ katem dążą w tym ujęciu do obiektywnej narracji, która udaje, że jest przeźroczysta, projektującej całkowicie biernego widza-obserwatora, przyjmującego za dobrą monetę to, co mu się pokazuje.

Autor adaptacji i scenariusza - Tadeusz Nyczek, bronił się, że spektakl nie był przewidziany do „Sceny Faktu”, skądinąd ważnej92, w której został umieszczony „mocą pewnego zbiegu okoliczności” (LM, s. 193). Podkreślał również, że i jemu, i Maciejowi Englertowi zależało „na stworzeniu normalnego widowiska t e a t r a ln e g o, w którym aktorzy grają zaprojektowane przez tekst, reżysera oraz własną wyobraźnię r o l e, a nie udają postaci historyczne [podkreślenia Tadeusza Nyczka]” (LM, s. 192). Dodawał także, że historia adaptacji powstałej z inicjatywy pracownika telewizji publicznej - Macieja Kosińskiego, była długa, sięgała 1995 r. (LM, s. 190-191). Z biegiem czasu w sprawę rzeczywiście miał się wmieszać IPN i zblokować realizację, pojawiły się bowiem ponoć jakieś dokumenty, wedle których „bohater AK-owskiego podziemia wcale nie był taki niezłomny, bo w zamian za odpuszczenie mu kary śmierci zobowiązał się napisać na zlecenie UB biografię Jürgena Stroopa" (LM, s. 191). Ostatecznie, jak pisze Nyczek, Rozmowy $z$ katem uratowały dla telewizji... obchody trzydziestolecia śmierci Moczarskiego" (LM, s. 192).

Z kolei Jan Kłossowicz porównał przedstawienie sprzed lat (z Teatru Powszechnego) z obecną realizacją i doszedł do wniosku, że „twórcy tamtego przedstawienia, chociaż nie mogli otwarcie i wyraźnie pokazać najbardziej dramatycznego aspektu więziennych przeżyć Moczarskiego - sytuacji świadomie stworzonej w 1949 r. przez oprawców z UB - to jednak potrafili ją wspaniale widzom uzmysłowić"93. Obecna inscenizacja/ekranizacja zaś, mimo iż „autorzy tego spektaklu mieli [dzięki nieobecności cenzury] niewspółmiernie prostsze od swoich poprzedników zadanie"94, nie wytrzymuje porównania z poprzedniczką przez swoją dosłowność. „Cały spek-

\footnotetext{
${ }^{90}$ Ibidem, s. 91 .

${ }^{91}$ Weronika Szczawińska, Niezłomni i transparentni, „Dialog” 2007, nr 10, s. 103.

92 Tadeusz Nyczek zauważał, „że w każdym z tych przypadków mamy do czynienia z mętną i długo zakłamywaną historią. Że choć niby już od brzęku kajdan wolni, nie jesteśmy wolni od śladów i odcisków, lęków i urazów z tamtych czasów” (idem, Lustrowanie Moczarskiego, „Dialog” 2007, nr 12, s. 190. Dalej cytuję jako LM).

${ }^{93}$ Jan Kłossowicz, Recenzja sprzed trzydziestu lat, „Przegląd Powszechny” 2007, nr 7-8, s. 280 .

${ }^{94}$ Ibidem, s. 281.
} 
takl stał się niespójny i mimo wielu dobrych scen nie oddał niesamowitego splotu skojarzeń, które wynikają z relacji o rozmowach z diabłem w ubeckim piekle, do którego Moczarski został wtrącony"95 - podsumował Kłossowicz.

Podobnego porównania dokonał Rafał Węgrzynek, ale doszedł do zgoła odmiennego wniosku:

Niektóre wspomnienia Stroopa, stanowiące jedynie przyczynek do portretu psychologicznego zbrodniarza, można było pominąć - chociaż wszystkie zostały świetnie wykorzystane przez Fronczewskiego. Natomiast więcej uwagi należało poświęcić źródłom niezłomnej postawy Moczarskiego. Telewizyjne Rozmowy $z$ katem, z pietyzmem odtwarzające historyczne realia [...], pozostawiają niedosyt z powodu nazbyt oszczędnego ukazania walki Moczarskiego o obronę prawdy i ocalenie godności ${ }^{96}$.

Trudno o bardziej rozbieżne opinie niż te Kłossowicza i Węgrzynka. Bez względu na to, czy uznamy je za zbyt bardzo czy zbyt mało dosłowne, telewizyjne Rozmowy $z$ katem czasów powszechnej lustracji za cel obrały sobie w pierwszej kolejności stalinizm, a ich odbiór stał się świadectwem dychotomii obu interpretacji - antynazistowskiej i antystalinowskiej.

\section{„Stał się symbolem honoru Armii Krajowej, tak nikczemnie poniewieranego przez nazistowskich i bolszewickich propagandystów"97. Postscriptum do Rozmów}

W zależności od czasów miały zatem Rozmowy z katem różnych katów. Tym, co najbardziej w całej sprawie niepokojące, jest marginalna obecność Holokaustu w dyskusjach nad książką. Jak to się stało, że książka, w której tak wiele miejsca poświęcone jest Zagładzie, nigdy nie była interpretowana w ten sposób, również przez osoby badające, gdzie pojawiają się opisy Zagłady? Czy powodem takiego stanu rzeczy były socjologizujące interpretacje koncentrujące się na postaci Stroopa, czy może te, które w książce Moczarskiego tropiły ślady stalinizmu? A może sam tekst skłaniał do pewnego typu odczytań? Kto dziś jeszcze - poza grupą specjalistów - pamięta, czytając Rozmowy z katem, że w archiwach IPN spoczywa jeden z najważniejszych dokumentów dotyczących Holokaustu - tzw. raport Stroopa dotyczący likwidacji getta warszawskiego ${ }^{98}$ ? Jakże znamienne jest, że przez ponad trzydzieści lat recepcji książki niemal nikt o tym dokumencie nie wspominał.

\footnotetext{
${ }^{95}$ Ibidem, s. 282 .

${ }^{96}$ Rafał Węgrzynek, Rozmowy z katami, „Teatr” 2007, nr 6, s. 57.

${ }^{97}$ Adam Michnik, $Z$ dziejów honoru i zgnilizny?, „Gazeta Wyborcza”, 18 X 2008, s. 14. Dalej cytuję jako DHiZ.

${ }^{98}$ Zob. Stanisław Piotrowski, Sprawozdanie Jürgena Stroopa, Warszawa: Spółdzielnia Wydawnicza Książka, 1948. Ponownie raport został wydany przez Instytut Pamięci Narodowej przy współpracy z Żydowskim Instytutem Historycznym w 2009 r. w opracowaniu i ze wstępem Andrzeja Żbikowskiego. Wydanie to zawiera faksymile niemieckiego oryginału tekstu i zdjęć. Zob. Jürgen Stroop, Żydowska dzielnica mieszkaniowa w Warszawie już nie
} 
Na zakończenie chciałbym wspomnieć o jeszcze jednym tekście, swoistym podsumowaniu i ukoronowaniu dotychczasowych interpretacji Rozmów z katem. Chodzi o artykuł Adama Michnika pt. $Z$ dziejów honoru i zgnilizny? Esej ten to kolejny wstęp, tym razem jednak do włoskiego, a nie polskiego wydania książki Moczarskiego, która jako Conversazioni con il boia ukazała się pod koniec 2008 r. w wydawnictwie Bollati Boringhieri.

Od początku Michnik nie ukrywa osobistego zaangażowania:

Nie czytałem tej książki z chłodnym obiektywizmem. Cały czas targały mną emocje: podziw i wzruszenie mieszały się z uczuciem braterstwa. I te emocje nie opuszczają mnie także teraz - gdy piszę. Trudno jest pisać zwyczajnie o człowieku niezwyczajnym (DHiz).

Autor godzi przy tym dwie interpretacje - $z$ jednej strony wpisuje Rozmowy w dzieje totalitaryzmu, wraz z pełnym zaufaniem w słowa narratora („Książka Kazimierza Moczarskiego [...] napisana została z chłodem godnym najwyższego szacunku”; DHiZ), z drugiej widoczny jest charakterystyczny dla nowego tysiąclecia antykomunistyczny rys, ujawniający się na przykład w wypowiedziach:

Ten pobyt $\mathrm{w}$ celi polskiego więzienia $\mathrm{z}$ generałem hitlerowskim jest symbolem losu polskiego $\mathrm{w}$ tamtych przeklętych latach - to przecież symbol klęski, poniżenia i ustawicznego zeszmatławiania Polski przez władzę komunistyczną (DHiZ)

czy

W sierpniu 1945 r. brama więzienna zatrzasnęła się nie tylko za Kazimierzem Moczarskim, dzielnym człowiekiem Armii Krajowej. Ta brama zatrzasnęła się także za wolną Polską (DHiZ).

Michnik podkreśla zatem heroiczny symbolizm postaci Moczarskiego, wpisując go w pewną wspólnotę antytotalitarnej, chrześcijańskiej, demokratycznej inteligencji, występującej przeciwko wszelkim faszyzmom (również spod znaku ONR), dogmatyzmom i totalitaryzmom. „Kazimierz Moczarski był dzieckiem tradycji Polski jagiellońskiej” -zauważa Michnik, dodając dalej, że autor Rozmów z katem uprawiał „szczególny polski etos. Etos unii horodelskiej, etos Jana Strzeleckiego, etos Jana Pawła II” (DHiZ). Zwraca zarazem uwagę, że „nie było nigdy jednego etosu polskiego”, bo przecież „ci, co go więzili i torturowali, także byli Polakami [...]. Polakami byli też ci, którzy w II RP głosili hasła faszystowskie, postulowali państwo dyktatury i dyskryminacji mniejszości narodowych, organizowali getto ławkowe na uniwersytetach i rozbijali stragany żydowskie" (DHiZ). Zasadniczo autor $Z$ dziejów honoru i zgnilizny?, posługując się bardzo ogólnymi, socjologicznymi kategoriami i dość prostymi opozycjami (chrześcijaństwo vs. nazizm, totalitaryzm vs. AK itd.), godzi interpretacje antytotalitarne oraz włącza się w tradycję

istnieje!, oprac. Andrzej Żbikowski, Warszawa: Instytut Pamięci Narodowej, 2009 (seria „Dokumenty”, t. 38). 
gloryfikowania postaci Moczarskiego. Mamy tu do czynienia z wyraźnie uniwersalizującą lekturą, przy czym analiza postaci Moczarskiego staje się wyrażeniem osobistego credo Michnika.

Tak dzieje się przez niemal cały esej, aż na samym końcu dochodzi do pewnego zawieszenia znanych już wątków, pojawia się bowiem postscriptum, a w nim pewna interpretacyjna rysa. Jest to najciekawszy fragment tego tekstu.

Owo zakończenie rozpoczyna się od przywołania mało znanego, skądinąd doskonałego, tekstu Michała Borwicza ${ }^{99}$, w którym autor Spod szubienicy w teren zauważa, że zastanawiająco dużo jest w tekście Rozmów fragmentów, w których powstanie w getcie jest ukazane jako walka ramię w ramię Polaków i Żydów przeciwko Niemcom. Sprawia to takie wrażenie, jakbyśmy mieli do czynienia nie z samotną walką Żydów, lecz wyraźnym współdziałaniem polsko-żydowskim, co pozostaje w jawnej sprzeczności z tym, co zarówno o samym powstaniu, jak i postawach Polaków względem niego wiemy ${ }^{100}$.

Rzeczywiście, jest to najbardziej wątpliwa część Rozmów. Moczarski pisze na przykład: „większość naszych zamierzeń wobec getta była natychmiast sygnalizowana Żydom przez wojskowy i cywilny wywiad polski” (RzK, s. 183), „Żydzi sa zdeterminowani, zorganizowani i wyposażeni oraz mają poparcie społeczeństwa polskiego i polskiej konspiracji wojskowej” (RzK, s. 194) czy:

Już pierwszego i drugiego dnia Wielkiej Akcji główna grupa bojowa Żydów przemieszana była z polskimi „franc-tireurami”. Wycofywała się w kierunku placu Muranowskiego, gdzie zasiliła ją większa liczba „aryjczyków”. Utrzymywali oni stałą łączność z AK, myślę, że przez kanały i specjalne podkopy przy murach getta. Miałem z tego powodu wiele trudności. Na placu Muranowskim stoczyliśmy zacięty bój. Polacy nie tylko walczyli w getcie, ale zaczepiali nas zbrojnie na terenach zewnętrznych (RzK, s. 205).

Można oczywiście bronić tej opowieści z wnętrza samej narracji, podkreślając, że jest to przecież relacja Stroopa. Może nazista nie odróżniał Żydów od Polaków, może próbował uzyskać jakieś korzyści (pozytywny obraz Polaków mógł wpłynąć na wyrok)? Sam Stroop zauważa jednak:

${ }^{99}$ Chodzi o: Michał Borwicz, Kazmierza Moczarskiego „Rozmowy z katem”, „Zeszyty Historyczne” (Paryż) 1980, z. 53, s. 177-185. Michnik nie podaje ani tytułu, ani danych bibliograficznych tego tekstu.

${ }^{100}$ Michał Borwicz pisał między innymi: „rozbieżności między wszystkimi dokumentami, świadectwami jednostek, polskich organizacji podziemnych i... samego Stroopa a odnośnymi stronicami książki Moczarskiego są podstawowe” (ibidem, s. 184). Autor tłumaczył to późniejszymi lekturami Moczarskiego, który modelował pozyskane od Stroopa informacje. Borwicz podkreślał również literacki charakter Rozmów, na przykład wypowiedź Stroopa: „myśmy szukali bunkrów po omacku, ja k pi ja ne dzie ci we m gle”, jest w istocie cytatem tytułu książki Boya, którego nazista nie mógł przecież znać. Podobnie wypowiedź Schielkego „Zdaje się, że pan nam b u j d y z a s u w a” [podkreślenia Michała Borwicza - B.K.], nosi wyraźne znamiona stylu Wiecha (ibidem, s. 178-179). 
Jeżeli mam ujawnić prawdę o powstaniu w getcie, to powiem, że Żydzi i pomagający im Polacy byli bohaterami. Ale za publiczne stwierdzenie tej prawdy muszę dostać zapłatę w formie dożywotniego więzienia, a nie szubienicy. Jeżeli zaś wyczuję, że muszę stracić głowę - niezależnie od tego, co powiem - to nie wykluczam, że zastosuję metodę kłamstwa. I zeznam, że cały ten żydowski opór był gównem i zabawką, że dziewczyny z Haluzzenbewegung to tchórzliwe histeryczki i że Polacy patrzyli obojętnie, a nawet aprobująco na likwidację Żydów... (RzK, s. 249),

co sam Moczarski kwituje kategorycznie:

- Czy pan myśli, że historia nie obnaży pańskich łgarstw, jeżeli pan się na nie zdecyduje? Przecież nie działał pan sam, tylko w bandzie. Tak jest. Niech się pan nie krzywi. Powtarzam: w bandzie esesowsko-gestapowskiej. Pan wie, jak było naprawdę. I ja wiem. I tysiące ludzi zna prawdę, niezależną od protokołów, rejentalnych oświadczeń i lakierowanych prac „historyków”... Ależ z pana numer! (RzK, s. 249-250).

Wierzymy zatem Stroopowi, że Polacy nie tylko „opanowali kanały pod gettem”(RzK, s. 203), w całej rozciągłości popierali powstanie (RzK, s. 238), ale stanowili podstawowe zagrożenie, którego należało się lękać. Co więcej - i to jest konstatacja szczególnie niepokojąca - stali się pełnoprawnymi ofiarami powstania („To pan, Herr Stroop, nic nie wiedział, że trupy Żydów w getcie z ostatnich dni Grossaktion są pomieszane z trupami Polaków więźniów Pawiaka, rozstrzelanych masowo przez podwładnych Hahna i z jego rozkazu? I że nie wszystkie późniejsze trupy z okresu majora Bundtkego były zwłokami Żydów?” - pyta Moczarski; RzK, s. 266).

Pamiętać trzeba także, że wizję, w której powstanie w getcie było w istocie powstaniem polsko-żydowskim, wspierają dotychczasowe omówienia książki (Moczarski jest szczery, obiektywny, dysponował nadnaturalną pamięcią itp.) oraz odautorski głos, który kategorycznie podkreśla: „Stroop nad podziw dobrze pamiętał przebieg Wielkiej Akcji” (RzK, s. 215), „wypowiedzi Stroopa uporządkowane przeze mnie, lecz nie ufryzowane” (RzK, s. 175) czy „nie uroniłem żadnego ze słów i podtekstów Jürgena Stroopa” (RZK, s. 196).

W ten sposób dochodzę do kwestii przyczynienia się samego tekstu do takiej, a nie innej jego recepcji. Recepcji, która generalnie pomijała zupełnie rolę Zagłady. Nie jest to konstatacja nowa, wszak już estetyka recepcji spod znaku Hansa Roberta Jaussa uczyła nas, że impuls interpretacyjny idzie tyleż z wnętrza tekstu, ile ze strony faktów i realiów społecznych. Zaprojektowane przez Moczarskiego sensy (w tym nieobecność Zagłady!) stają się swoistą partyturą, która wzbudza rezonans kolejnych odczytań101.

101 „Dzieło literackie nie jest przedmiotem samym w sobie, który każdemu odbiorcy w każdym czasie ukazuje się tak samo. Nie jest pomnikiem, który monologicznie objawia swą ponadczasową istotę. Jest raczej jak partytura nastawiona na wciąż ponawiany rezonans odczytania, które wyzwala tekst z materii słowa i nadaje mu aktualne istnienie” - pisał Hans 
Wracając do tekstu Michnika, podejmuje się on obrony Moczarskiego. W postscriptum $Z$ dziejów honoru i zgnilizny? zauważa mianowicie, że relacja pisarza jest „selekcją faktów przez pamięć” (DHiZ), książka poddana była również autocenzurze, przede wszystkim zaś stanowiła twór czasu, w którym powstawała, a więc 1968 r. Michnik podkreśla w zakończeniu eseju:

W tym momencie każdy polski demokrata miał w podświadomości dwa pragnienia: wyrazić sprzeciw wobec stereotypów antysemickich wśród Polaków, na nowo zaszczepionych przez reżim komunistyczny, i sprzeciwić się stereotypowi Polaka antysemity za granicą. Oba te sprzeciwy odnalazłem - ukryte w narracji - w książce Moczarskiego. Wreszcie - człowiek zapamiętuje często to, co lubi pamiętać, to, co krzepi jego serce. Dlatego w Rozmowach z katem Moczarski kreśli inny, szlachetny wizerunek Żydów i inny, szlachetny wizerunek Polaków. Z najnowszych badań nad historią wiadomo, że oba te wizerunki są mocno wyidealizowane. Książka Moczarskiego jest świadectwem rozmów więziennych ze Stroopem. Jest ona również świadectwem reakcji autora na hańbę antysemityzmu w Polsce w 1968 r. Oba te świadectwa zasługują na najwyższy szacunek (DHiZ).

Dziś Rozmowy z katem wymagają z pewnością nowego odczytania. Bardzo ciekawe byłoby komparatystyczne ujęcie, zestawiające odbiór książki Moczarskiego w różnych krajach i konfrontujące je ze stereotypowymi wizerunkami Niemców, obecnymi choćby w Lektorze Bernharda Schlinka (i jego ekranizacji z 2008 r.) oraz Białej wstążce Michaela Hanekego z 2009 r. Na koniec wreszcie - należałoby na nowo przeczytać Rozmowy z katem po kontrowersyjnych Łaskawych Jonathana Littella ${ }^{102}$. Przede wszystkim jednak należałoby Rozmowy przeczytać od początku, by wreszcie dostrzec w nich i właściwie pojacć takie na przykład fragmenty:

Płomieniami, żarem i dymem wykurzyliśmy Żydów! Panie, jak oni od tego podsmażenia i wędzenia krzyczeli! Z jaką chęcią oddawali się do niewoli! Co prawda część popełniła samobójstwo, lecz resztę wysiedliliśmy i... natychmiast do wagonów, do Treblinki! (RzK, s. 203).

Piękną klamrą oficjalnego zamknięcia Wielkiej Akcji było wysadzenie w powietrze Wielkiej Synagogi przy ulicy Tłomackie. Przygotowania trwały dziesięć dni. Trzeba było opróżnić jej wnętrze oraz wyborować $\mathrm{w}$ fundamentach i murach kilkaset otworów na materiały wybuchowe. Synagoga była gmachem solidnie zbudowanym. Stąd, aby ją za jednym zamachem wysadzić w powietrze, należało przeprowadzić pracochłonne roboty saperskie i elektryczne.

Robert Jauss. Zob. idem, Historia literatury jako prowokacja, tłum. Małgorzata Łukasiewicz, Warszawa: Wydawnictwo IBL, 1999, s. 143-144.

102 Jonathan Littell, Łaskawe, tłum. Magdalena Kamińska-Maurugeon, Kraków: Wydawnictwo Literackie, 2009. 
- Ależ to był piękny widok! - opowiadał z błyskiem w oku Stroop. - Z punktu widzenia malarskiego i teatralnego obraz fantastyczny! Staliśmy z moim sztabem dość daleko od Synagogi. Oficer saperów, odpowiedzialny za prawidłowe wysadzenie w powietrze, wręczył mi, za pośrednictwem Maxa Jesuitera, aparat elektryczny wywołujący poprzez przewody elektryczne jednoczesną detonację ładunków wybuchowych w murach Synagogi. Jesuiter nakazał ogólną ciszę. W blasku płonących budynków stali zmęczeni i umorusani moi i dzielni oficerowie i żołnierze. Przedłużałem chwilę oczekiwania. W końcu krzyknąłem: Heil Hitler! - i nacisnąłem guzik. Ognisty wybuch uniósł się do chmur. Przeraźliwy huk. Feeria kolorów. Niezapomniana alegoria triumfu nad żydostwem. Getto warszawskie skończyło swój żywot. Bo tak chciał Adolf Hitler i Heinrich Himmler (Rzk, s. 243).

\title{
Słowa kluczowe
}

socjologia literatury, powstanie w getcie warszawskim, Zagłada, Kazimierz Moczarski, Jürgen Stroop

\begin{abstract}
Abtract
The articles discusses Polish reception of Kazimierz Moczarski's book. The story's outline refers to the three main editions of the Conversations with an Executioner. Each of those editions features a meaningful introduction setting certain senses of the reading of the book and simultaneously being its testimonies:

- Państwowy Instytut Wydawniczy edition with Franciszek Ryszka's introduction (five editions during 1977-1985),

- Państwowe Wydawnictwo Naukowe edition with Andrzej Szczypiorski's introduction (ten editions during 1992-2002) and

- the Znak edition with Norman Davies's introduction (three editions since 2004). Adam Michnik's essay is a certain culmination of those introductions - it is another introduction but this time to an Italian edition.

Analyzing the statements of the reviewers and introductions' authors, the author investigates the social reception of the book. Here, he devotes particular attention to the social image of an execution and the images (or actually their absence) of the Holocaust, which emerged as a result of the reception of the book.
\end{abstract}

\section{Key words}

literature sociology, Warsaw ghetto uprising, Holocaust, Kazimierz Moczarski, Jürgen Stroop 